\title{
Correction to: Müllerian Duct Anomalies
}

Nkeiruka Ameh, Adebiyi Gbadebo Adesiyun, Ismael E. Elhalaby, Hesham M. Abdelkade, and Essam A. Elhalaby

Correction to: Chapter 116 in: E.A. Ameh et al. (eds.), Pediatric Surgery, https://doi.org/10.1007/978-3-030-41724-6_116

The original version of this chapter was inadvertently published with incorrect name of the second author as 'Gbolahan Adesiyun' whereas it should be 'Adebiyi Gbadebo Adesiyun'.

The author name has now been updated with this erratum. 